\title{
Physico-Chemical Assessment of Surface and Ground Water for Drinking Purpose in Nawabshah City, Sindh, Pakistan
}

\author{
Abdul Jabbar Kandhro", Ali Muhammad Rind ${ }^{2, ~ *, ~ A b d u l ~ A z i z ~ M a s t o i ~}{ }^{2}$, Khalida Faryal Almani ${ }^{2}$, \\ Sujo Meghwar ${ }^{3}$, Muhib Ali Laghari ${ }^{3}$, Muhammad Sohaib Rajpout ${ }^{2}$ \\ ${ }^{1}$ Department of Community Medicine, Peoples University of Medical \& Health Sciences for Women, Nawabshah, Shaheed Benazirabad \\ ${ }^{2}$ Center for Environmental Sciences, University of Sindh, Jamshoro, Sindh, Pakistan \\ ${ }^{3}$ Department of Geography, University of Sindh, Jamshoro, Sindh, Pakistan
}

Email address:

ali_mohmedr@yahoo.com (A. M. Rind)

\section{To cite this article:}

Abdul Jabbar Kandhro, Ali Muhammad Rind, Abdul Aziz Mastoi, Khalida Faryal Almani, Sujo Meghwar, Muhib Ali Laghari, Muhammad Sohaib Rajpout. Physico-Chemical Assessment of Surface and Ground Water for Drinking Purpose in Nawabshah City, Sindh, Pakistan. American Journal of Environmental Protection. Vol. 4, No. 1, 2015, pp. 62-69. doi: 10.11648/j.ajep.20150401.19

\begin{abstract}
The work reports the analysis of groundwater and surface water samples, were collected from different towns of Nawabshah City during the end of year 05 Dec, 2013 to 30 Jan, 2014. Sixty five groundwater and sixty surface water samples (water supply scheme) were collected from different parts of the Nawabshah city. Different physico-chemical parameters of water samples were measured at the field and in the laboratory. The conductivity, salinity and Total dissolved solids (TDS) were measured with Orion 115 conductivity meter at the field. $\mathrm{pH}$ was recorded with Orion $420 \mathrm{~A} \mathrm{pH}$ meter. Total hardness, chloride and alkalinity were determined by titration with standard EDTA, silver nitrate and hydrochloric acid. Sulfate was determined by turbidity meter as $\mathrm{BaSO} 4$ using Hitachi spectrophotometer. The metal ions $\mathrm{Na}, \mathrm{K}, \mathrm{Ca}$ and $\mathrm{Mg}$ were determined with Varian Spectr. AA-20 atomic absorption spectrometer with standard burner head and air acetylene flame at conditions recommended by the manufacturer. The results were varied within the ranges; $\mathrm{pH} 6.64-8.87$, EC 240-10170 $\mu \mathrm{S} / \mathrm{cm}$ and TDS $158-6050 \mathrm{mg} / \mathrm{l}$, alkalinity $56-1225 \mathrm{mg} / \mathrm{l}$, total hardness $84-1695 \mathrm{mg} / \mathrm{l}$, chloride $32-1852 \mathrm{mg} / \mathrm{l}$, sulfate $25-2170 \mathrm{mg} / \mathrm{l}$. The concentration of essential metals was found in the ranges; Na 34-1725 mg/l, Ca 26-515 mg/l, Mg 13-430 mg/l, K 2-92 mg/l respectively. The analysis revealed that a number of ground water samples $(70 \%)$ confirm their majority of parameters above the maximum permissible limits prescribed by WHO. Therefore the ground water of Nawabshah city may not be considered as safe to be used for dinking purpose. However, out of 60 samples only four surface water samples may be used for drinking purpose.
\end{abstract}

Keywords: Canal Water, Water Supply Schemes, Ground Water, Physical, Chemical

\section{Introduction}

Nowadays Safe drinking water is a major issue mostly in developing countries (1), drinking of polluted water generate serious health issues, may be consumption of contaminated water is a cause of high death rate in developing countries. Most of the cities of world use underground water for their daily use, which is contaminated by sewage. Over all the Word approximately 800 million peoples not getting adequate water supply (2). Water in developed countries used after proper filtration procedure but in developing countries it is inverse, lake of filtration plants leads to use contaminated water to peoples which affected severally. Diarrhea is common in Pakistan due to utilizing contaminated water. Water which safe for drinking purpose called potable water. Water gets polluted by two major sources i.e. point sources and non point sources.

The water in the Indus basin is of variable quality (3-5). It is not saline near sources of recharge, i.e. rivers and major canals but gradually becomes saline with depth as the distance from the recharge source increases (6). Poor microbial quality of drinking-water is the most pressing issue. No urban water supply meets WHO drinking-water quality guidelines (7). The major reasons for this are the intermittent supply through leaking pipes and cross connections with 
nearby sewer lines (8). People of the district mostly use underground water for drinking purpose, except some towns, where the water supply schemes provide surface water for drinking. The water we drink should meet some national and international standards. It is also predicted that in future Pakistan will face water challenges (9-11). Chemical composition of surface and groundwater is one of the major factors to which the suitability of water for industrial, domestic and agricultural purpose depends (12). The pollution of groundwater results from all the processes and reactions which the water faces from the moment it condensed in the atmosphere to the time it is discharged by a well or hand pump and varies from place to place with depth. Major portion of the rural Inhabitants depend upon the groundwater due to unavailability of water treatment and supply of potable water. $40 \%$ of the deaths in Pakistan are caused by water borne diseases directly or indirectly (13).

A number of factors cause pollution of surface as well groundwater including urbanization and industrialization. The quality of groundwater in Drinking Water Quality of Pakistan is deteriorating day by day (14-20). A serious problem appears due to stagnant management of effluent water which becomes penetrating into the soil with the passage of time and can become a part of natural and ground water $(6,21-25)$.

Lot of work has been carried out on the quality of ground water of different parts of Pakistan (26). Mostly the water of all the sources in Pakistan is polluted (27). The drinking water of different regions of country also contaminated including Peshawar (28, 29), Karachi (30), Lahore (31), Muzaffargarh (32) and Tharparkar (33), but no any reasonable work is reported on the quality of underground water of Nawabshah city.

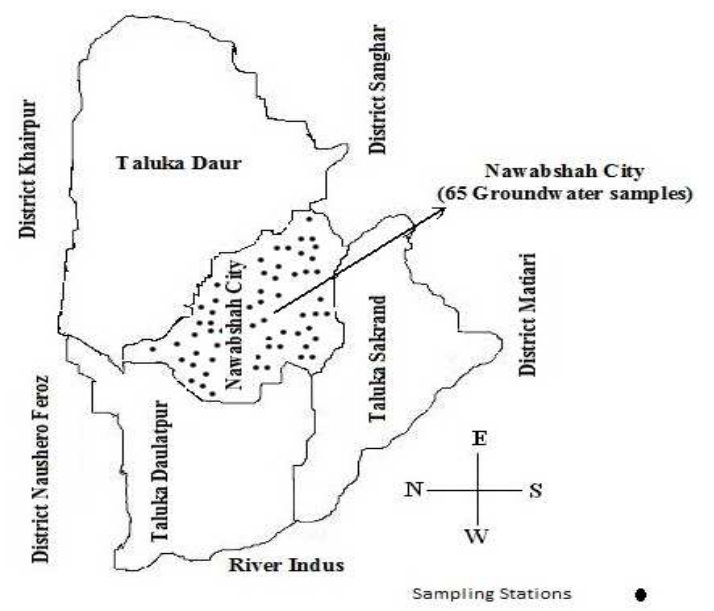

Map 1. District Nawabshah and ground water sampling stations.

The quality of water in domestic use must be tested to know the extent of its pollution and its suitability for human consumption. It is useful to examine the above highlighted problems in an environmental frame work in which the quantity and quality of water resources is a major concern. The object of this study is to assess the drinking water quality in various drinking water sources used in Nawabshah city. In Nawabshah both the underground and surface (Municipal whole water quality of the city and compare it with the standards of World Health Organization. Over all focus of this study was drinking water quality of the city.

\section{Materials \& Methods}

Samples were collected from the municipal water supply and underground water in pre sterilized polyethen bottles, before the collection of samples bottles were washed with sample water twice. All the reagents used were of analytical grade and all the glass ware used was washed properly with double distilled water before use. The metal standard solutions were prepared by dilution from 1000 ppm stock solution of each metal.

\subsection{Detection of Physical Parameters}

Different physico-chemical parameters of water samples were measured at the field and in the laboratory. The homogenized sample was transferred to a clean $1 \mathrm{~L}$ clean plastic bottle. The temperature of air on meter above the surface of water was recorded with mercury thermometer, conductivity, salinity and total dissolved solids (TDS) were measured with Orion 115 conductivity meter at the field. $\mathrm{pH}$ was recorded with Orion 420A pH meter.

\subsection{Detection of Chemical Parameters}

Hardness, chloride and alkalinity were determined by titration with standard EDTA, silver nitrate and hydrochloric acid respectively. Sulfate was determined by turbidity meter as $\mathrm{BaSO}_{4}$ using double beam Hitachi 220 spectrophotometer.

\subsection{Detection of Metallic Ions}

The essential metal ions ( $\mathrm{Na}, \mathrm{K}, \mathrm{Ca}$ and $\mathrm{Mg}$ ) were determined with Varian Spectra AA-20 atomic absorption spectrometer with standard burner head and air acetylene flame. The analysis was carried out in triplicate with integration time 3 seconds and delay time 3 seconds. The concentration of metal ions ( $\mathrm{Na}, \mathrm{K}, \mathrm{Ca}$ and $\mathrm{Mg}$ ) was determined after appropriate dilution of the sample containing $1 \mathrm{ml}$ concentrated nitric acid per $250 \mathrm{ml}$. The SAR values were calculated using the formula, $\mathrm{SAR}=\mathrm{Na}$ / (Ca+Mg) 1/2/2.

\section{Results and Discussion}

The work reports the analysis of groundwater and some surface water samples from Nawabshah city, located at the center of Sindh province. The results of physical and chemical parameters of the water samples were found in the following ranges. $\mathrm{pH}$ 6.64-8.87, TDS 158-6050 mg/L, chloride 32-1852 $\mathrm{mg} / \mathrm{L}$, alkalinity-M 56-1225 mg/L, hardness $84-1695 \mathrm{mg} / \mathrm{L}$, $\mathrm{SO}_{4} 25-2170 \mathrm{mg} / \mathrm{L}$, The concentration of essential metal ions ( $\mathrm{Na}, \mathrm{Ca}, \mathrm{Mg}$ and $\mathrm{K}$ ) was found in the ranges of $34-1725 \mathrm{mg} / \mathrm{L}$, 26-515 mg/L, 13-430 mg/L and 2-92 mg/L respectively. The 
results revealed that the majority of ground water samples (40 out of 65) of the study area were not suitable to be used for drinking purpose; on the other hand, 40 water samples based on sodium adsorption ratio (SAR) were found suitable to be uses for irrigation purpose.

In all the natural ecosystems water acts as the primary transport medium for dissolved and particulate matter and determines as well, the rate at which these fluids are added or removed from the system. A complete identification of hydrological characteristics is hence essential for understanding biological, chemical and physical processes that operate within the ecosystem.

The results of physico-chemical parameters of water samples reveal the varying nature of the underground water of the Nawabshah city. The difference in the quality of groundwater may be due to topography of soil; different earth beds and effect of recharge sources (canals etc) on underground water.

\section{1. $\mathrm{pH}$}

The $\mathrm{pH}$ of water samples varied between within the range 6.95-8.87. Sixty three samples confirm $\mathrm{pH}$ within the safe guidelines of 6.5-8.5 prescribed by WHO for drinking water, while only two samples were above the limits of WHO. These two samples were collected direct from Gajra (canal) running through Nawabshah city and from a hand pump located near to Gajra (canal). The high values of $\mathrm{pH}$ may be due to human activity (domestic and industrial waste) and water logging respectively. The waters with $\mathrm{pH}$ below 7.0 are termed as acidic and acidity in water is due to the presence of dissolved carbonic acid. It increases the solubility of different materials including metals ions like $\mathrm{Na}, \mathrm{K}, \mathrm{Ca}$ and $\mathrm{Mg}$. Twenty samples indicated $\mathrm{pH}$ below 7.0 but indicated within the permissible limit of 6.5 .

\section{pH in Ground Water}

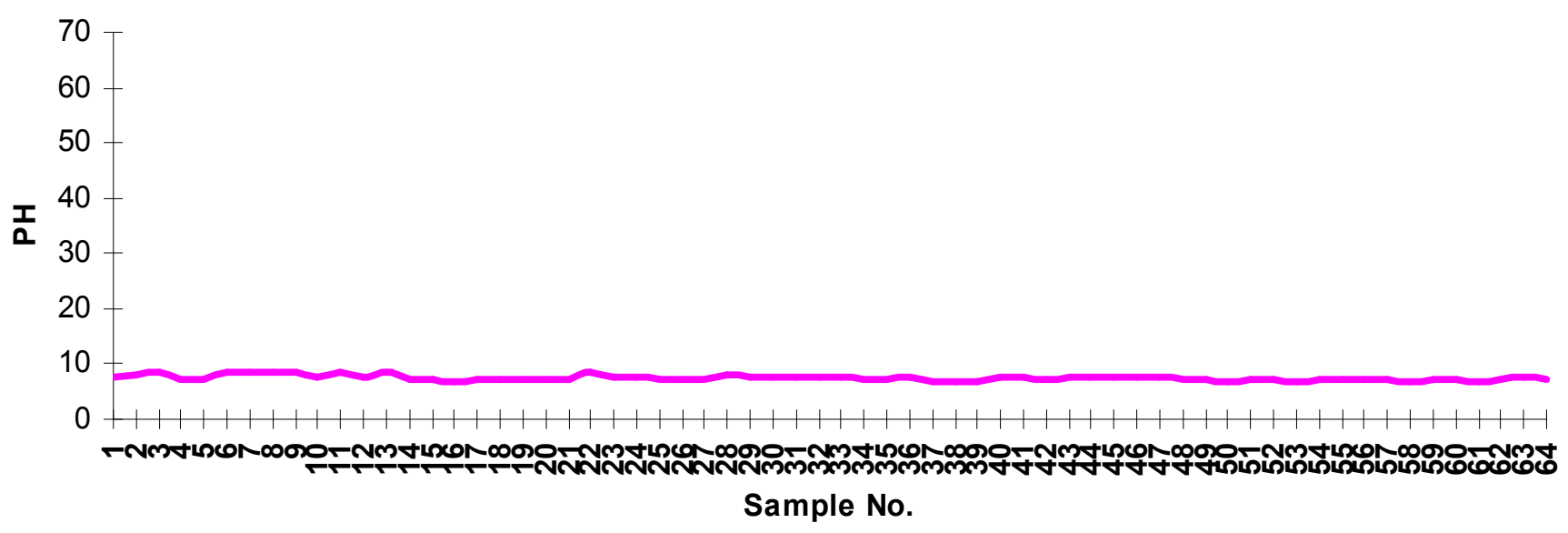

Figure 1. $p H$ in Ground Water.

pH in Surface Water Supply

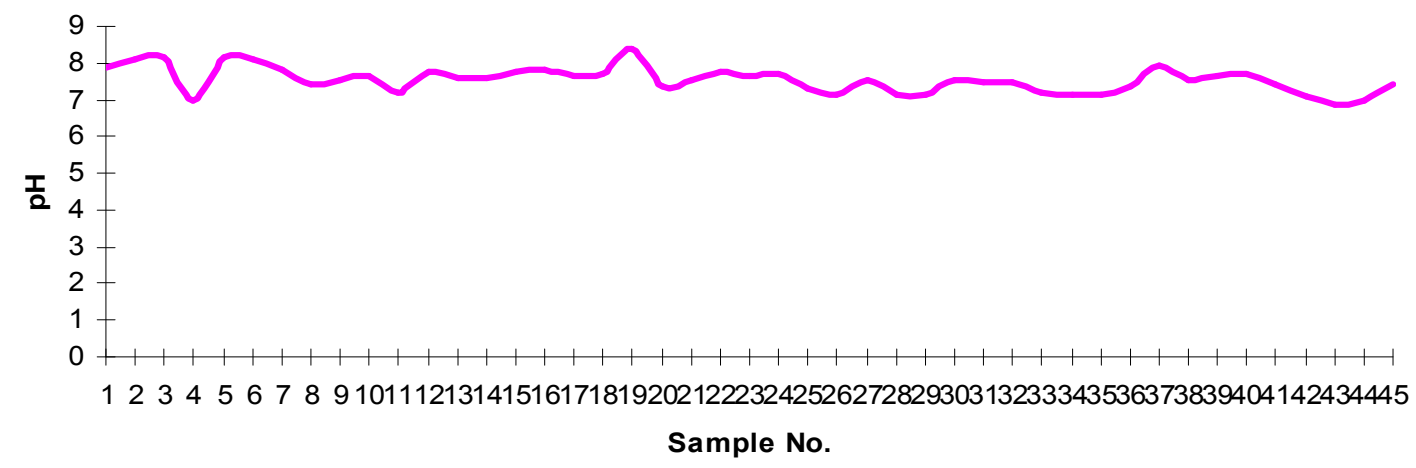

Figure 2. pH in Surface Water Supply.

\subsection{Total Dissolve Solids (TDS)}

The TDS varied between within the range 158-6050 mg/L. A lot of variation was observed in TDS of water samples, only 10 samples were observed within the limits $(500 \mathrm{mg} / \mathrm{L})$ of WHO for drinking water. The variation in TDS may be due to different earth beds and recharge sources. Generally the water samples have high values of TDS making them unsuitable for drinking purpose. The water samples with elevated values of TDS may cause several health problems to 
living organisms and adversely affect the fertility of soil, if used for irrigation purpose.

\section{TDS in Ground Water in Mg/L}

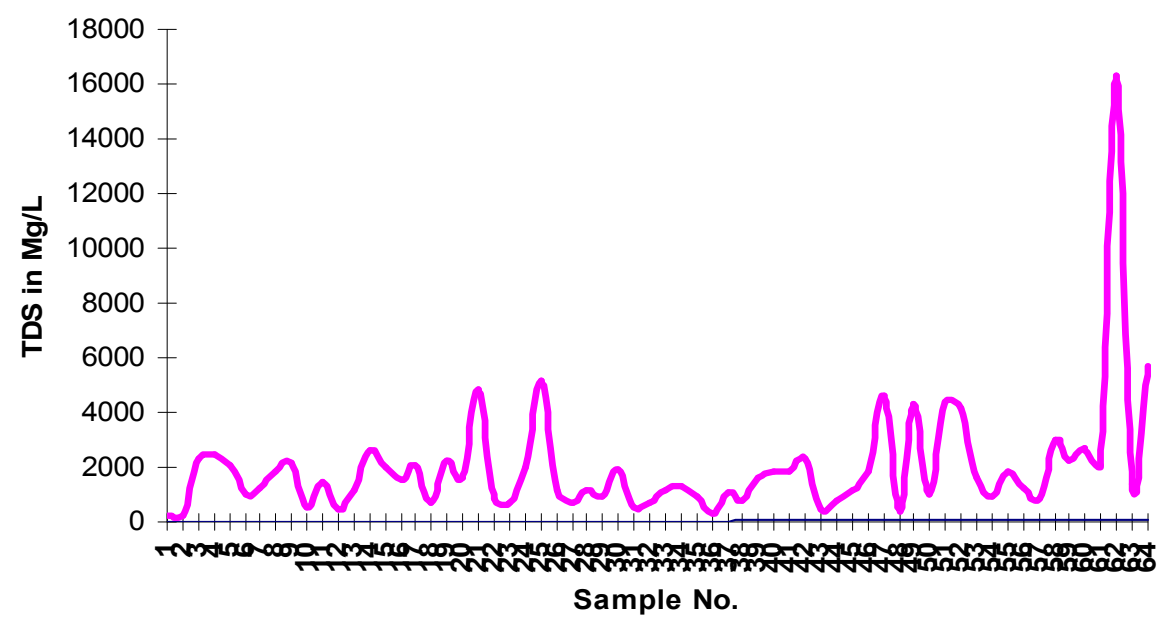

Sample No. TTS mg/L $<800$ mg/l

Figure 3. TDS in Ground Water.

TDS in Surface Water Supply in Mg/L

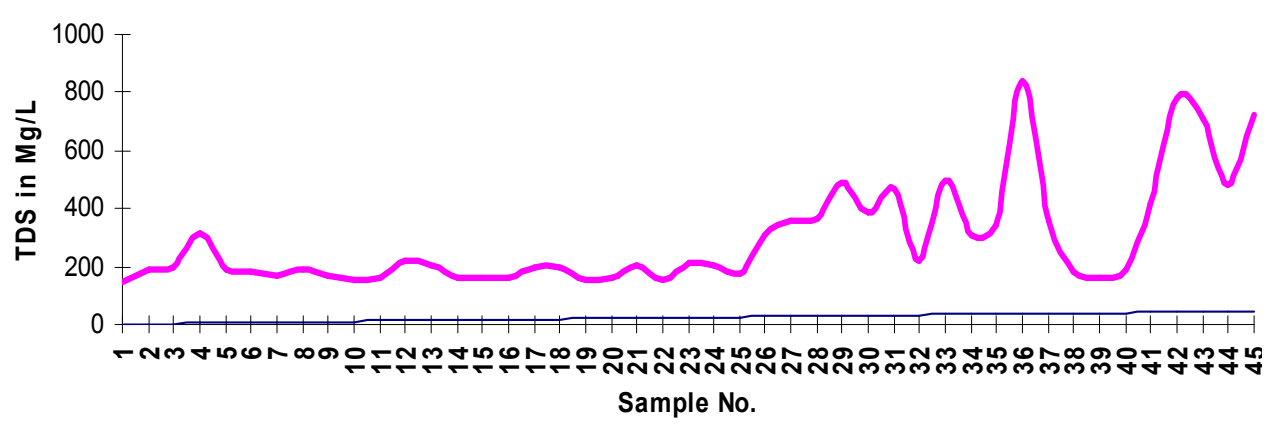

Sample No. TDS mg/L $<800 \mathrm{mg} / \mathrm{l}$

Figure 4. TDS in Surface Water Supply.

\subsection{Bicarbonates and Hardness}

The contents of bicarbonate and hardness fluctuated varied between within the range $56-1225 \mathrm{mg} / \mathrm{L}$ and $84-1695 \mathrm{mg} / \mathrm{L}$ respectively. A parallel behavior of bicarbonate with hardness was noted. Hardness of 25 samples was within the safe limits prescribed by WHO for drinking water and six samples indicated their hardness above $700 \mathrm{mg} / \mathrm{L}$ may be due to geological reasons. The water with elevated hardness than the WHO guidelines may cause gastric problems, dehydration, gas trouble, kidney stone and heart problems. 10

\subsection{Chloride and Sulfate}

The concentration of chloride varied between within the range $32-1752 \mathrm{mg} / \mathrm{L}$. Nearly half of the samples (35 samples) showed their chloride concentration above the regulations $(250 \mathrm{mg} / \mathrm{L})$ set by WHO. The chloride in water is present in combination with sodium, calcium and magnesium. Sources of chloride are mostly human waste, mineral rocks, irrigation discharge and industrial effluents like dying and bleaching materials. The water samples with higher concentration of chloride may have toxic effects to health.

The Sources of sulfate in surface and subsurface water are mainly calcium sulfate and sodium sulfate. The sulfates entering in water bodies come from dissolution of minerals containing sulfides and thiosulfates. Sulfate contributes to the permanent hardness to water. The elevated level of sulfate in water causes bad taste of water and also shows corrosive action (34). Sulfate was found between 25- 2170 $\mathrm{mg} / \mathrm{L}$. Some of the water samples (20 samples) indicated their sulfate contents above the limits of WHO. These samples were collected from Kazi Ahmed road of Nawabshah city. A parallel trend was found in the concentrations of chloride and sulfate in water samples (35).

The concentration of essential metal ions ( $\mathrm{Na}, \mathrm{Ca}, \mathrm{Mg}$ and $\mathrm{K})$ was varied between the ranges of 34-1725 mg/L, 26-515 
$\mathrm{mg} / \mathrm{L}, 13-430 \mathrm{mg} / \mathrm{L}$ and 2-92 $\mathrm{mg} / \mathrm{L}$ respectively.

Concetration of $\mathrm{Na}, \mathrm{K}, \mathrm{Ca}$ and $\mathrm{Mg}$ in Ground Water

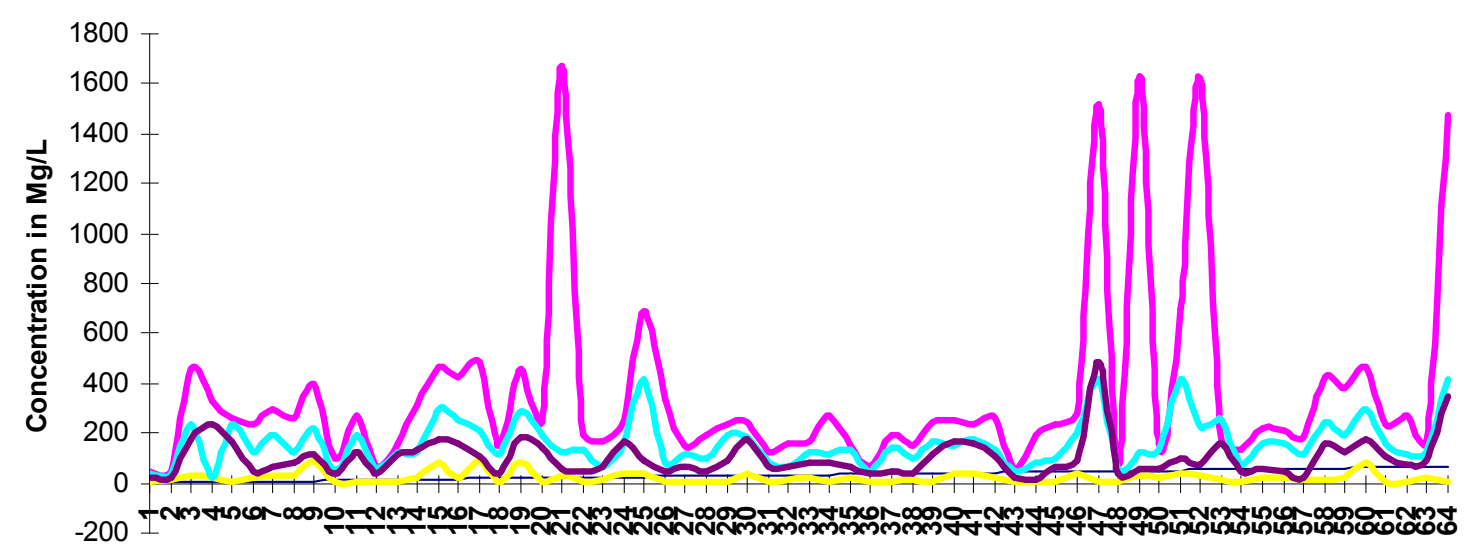

Sample No.

Sample No. $\longrightarrow$ Na mg/L $<175 \mathrm{mg} / \mathrm{l} \longrightarrow \mathrm{K} \mathrm{mg} / \mathrm{L}<12 \mathrm{mg} / \mathrm{l} \longrightarrow$ Ca $\mathrm{mg} / \mathrm{L}<100 \mathrm{mg} / \mathrm{l} \longrightarrow \mathrm{Mg} \mathrm{mg} / \mathrm{L}<50 \mathrm{mg} / \mathrm{l}$

Figure 5. Concentration of $\mathrm{Na}, \mathrm{K}, \mathrm{Ca}$ and $\mathrm{Mg}$ in Ground water.

\section{Concentration of $\mathrm{Na}, \mathrm{K}, \mathrm{Ca}$ and $\mathrm{Mg}$ in Surface Water Supply}

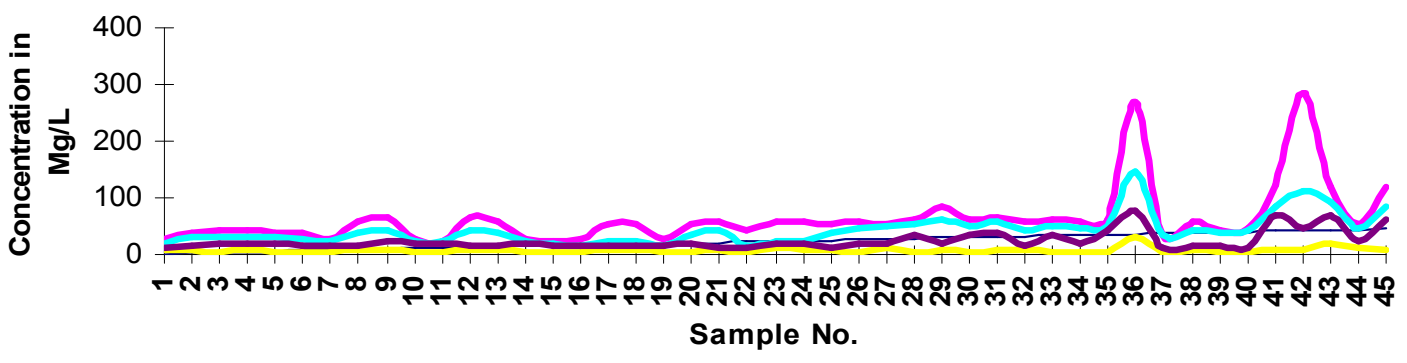

\begin{tabular}{|l}
- Sample No. \\
Ca mg $/ \mathrm{L}<100 \mathrm{mg} / \mathrm{l} / \mathrm{L}<175 \mathrm{mg} / \mathrm{l} \longrightarrow \mathrm{K} \mathrm{mg} / \mathrm{L}<12 \mathrm{mg} / \mathrm{l}$ \\
$\mathrm{Mg} \mathrm{mg} / \mathrm{L}<50 \mathrm{mg} / \mathrm{l}$
\end{tabular}

Figure 6. Concentration of $\mathrm{Na}, \mathrm{K}, \mathrm{Ca}$ and $\mathrm{Mg}$ in Surface Water Supply.

\subsection{Chemistry of Metal Elements}

The concentration of major metal ions $\mathrm{Na}, \mathrm{K}, \mathrm{Ca}$, and $\mathrm{Mg}$ varied with high concentration of ground samples. The concentration of major metal ions follows following decreasing order:

$$
\mathrm{Na}>\mathrm{Ca}>\mathrm{Mg}>\mathrm{K}
$$

Sodium is present in all natural waters. The presence of sodium in water depends upon the anions present in that system and the temperature. The high concentration of sodium impart taste to the water and make it unfit for everyday use and leads to cardiovascular diseases and high blood pressure (36). Concentration of $\mathrm{Na}$ in water samples of the study area varied as $34-1725 \mathrm{mg} / \mathrm{L}$. The $\mathrm{Na}$ ion concentration of the 25 samples was found with in the safe guidelines of $200 \mathrm{mg} / \mathrm{L}$ set by WHO for drinking water. All the rest of the samples indicated high values of $\mathrm{Na}$ ion concentration than WHO limits.
Potassium plays an important role in the metabolism process of animals and, it is an important micronutrient for living organisms (plants and animals). The WHO threshold of potassium for drinking water is $12 \mathrm{mg} / \mathrm{L}$. The potassium concentration of the water samples studied was varied between 2-92 $\mathrm{mg} / \mathrm{L}$, including 40 samples with $\mathrm{K}$ ion concentration within the permissible limits.

Calcium and magnesium are abundant in rocks and soil, particularly lime stones and dolomites. They are relatively soluble and dissolve in surface water and then enter into ground water. There are no health concerns associated with calcium and magnesium, but the water containing these metals may contribute towards human dietary needs, however, their high concentration may cause scaling of pipes. The concentrations of $\mathrm{Ca}$ and $\mathrm{Mg}$ ions in the water samples of the area were found in the ranges of $26-515 \mathrm{mg} / \mathrm{L}$ and $13-$ $430 \mathrm{mg} / \mathrm{L}$ respectively. $\mathrm{Ca}$ in 40 samples and $\mathrm{Mg}$ in 45 samples were found to be within the permissible limits of WHO. The rest of the water samples were observed very 
hard with high concentrations of $\mathrm{Ca}$ and $\mathrm{Mg}$.

Hardness, Alkalinity, Sulfate and Chloride in Ground Water in Mg/L

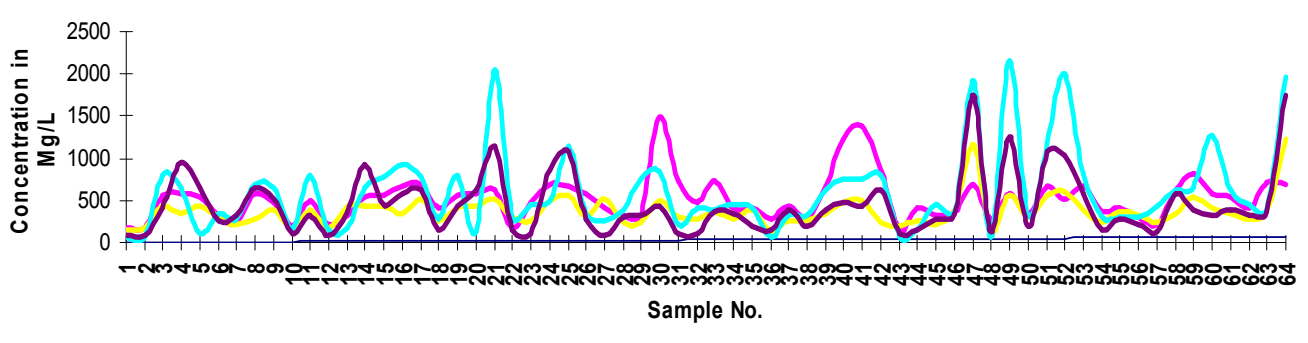

\begin{tabular}{|ll|}
\hline - Sample No. & - Hardness as $\mathrm{CaCO} 3 \mathrm{mg} / \mathrm{L}<500 \mathrm{mg} / \mathrm{l}$ - Alkalinity-M mg/L $<500 \mathrm{mg} / \mathrm{l}$ \\
- Sulfate $\mathrm{mg} / \mathrm{L}<500 \mathrm{mg} / \mathrm{l}$ & Chloride $\mathrm{mg} / \mathrm{L}<200 \mathrm{mg} / \mathrm{l}$
\end{tabular}

Figure 7. Hardness, Alkalinity, Sulfate and Chloride in Ground Water in $\mathrm{Mg} / \mathrm{L}$.

Hardness, Alkalinity, Sullfate and Chloride in Surface Water Supply

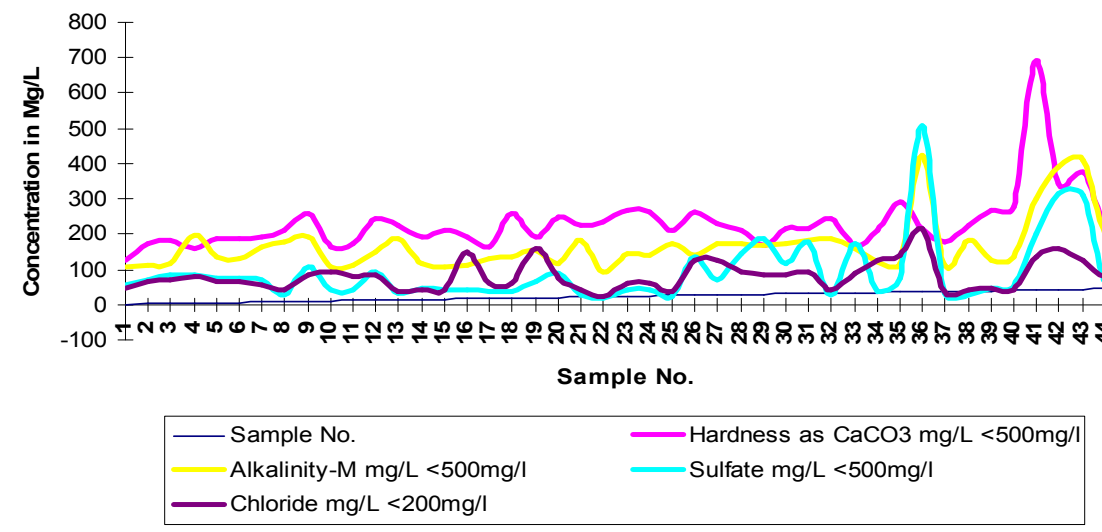

Figure 8. Hardness, Alkalinity, Sulfate and Chloride in Surface Water Supply $M g / L$.

\subsection{Sodium Adsorption Ratio (SAR)}

Sodium adsorption ratio (SAR) was calculated to check the suitability of the waters to be used for irrigation purpose. The results revealed that determined 125 samples, only (60 surface water and 40 under groundwater) were suitable for irrigation with SAR value below 6 and remaining 25 samples were unsuitable for irrigation with SAR value above 6 , all these 25 samples were under groundwater samples "Figure 9".

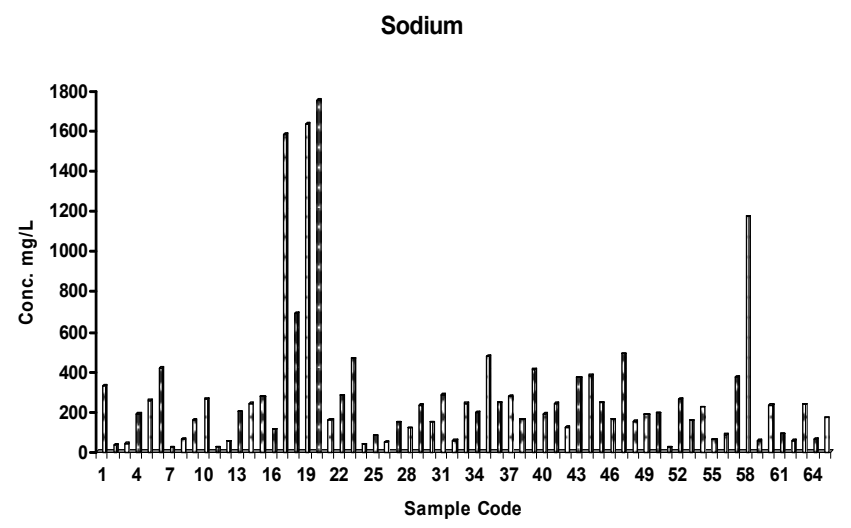

Figure 9. Graphical representation of $\mathrm{Na}$ ion concentration of water samples.

\section{Conclusion}

The analysis revealed that a number of ground water samples $(70 \%)$ showed their majority of parameters above the maximum permissible limits prescribed by WHO. Majority of the sites (all ground waters) were highly contaminated with toxic metals. The higher the concentrations of metals in ground water may be a concern for human health of Nawabshah city. Therefore the ground water of Nawabshah city may not be considered as safe to be used for dinking purpose. However, out of 60 water supply scheme samples, only 4 water samples may be used for drinking purpose and remaining all the water samples were contaminated.

\section{References}

[1] S. Khan, M. Shahnaz, NoorJehan, S. Rehman, M. T. Shah and I. Din. Drinking water quality and human health risk in Charsadda district, Pakistan. Journal of Cleaner Production. Vol. 60, pp. 93-101, December 2013.

[2] WHO, progress on drinking water and sanitation, World Health Organization, Geneva, Switzerland, 2012. 
[3] T. Ahmad, P. P. Khanna, G. J. Chakrapani and S. Balakrishnan, Geochemical characteristics of water and sediment of the Indus river, Trans-Himalaya, India: constraints on weathering and erosion. Journal of Asian Earth Sciences. Vol. 16, pp. 333-346 April-June 1998.

[4] A. S. Qureshi, P. G. McCornick, M. Qadir and Z. Aslam, Managing salinity and water logging in the Indus Basin of Pakistan. Agricultural Water Management. Vol. 95, pp. 1-10, January 2008

[5] S. K. Jain, P. K. Agarwal and V. P. Singh, Indus Basin. Water Science and Technology Library Vol. 57, pp. 473-511, 2007.

[6] M. Y. Khuhawar and S. A. Majidano. An investigation of quality of groundwater of taluka Nawabshah. Pak. J. Chem. Vol. 1, pp. 65-71, 2011.

[7] Guidelines for drinking water quality, 2nd ed. Geneva, WHO, 1995.

[8] Abu-Amr and M. M. Yassin. Microbial contamination of the drinking water distribution system and its impact on human health in Khan Yunis Governarate, Gaza strip. J. Royal Inst. Public Health, 10, pp. 10-16, 2008. PCRWR. National Water Quality Monitoring Program. Water Quality Report 20032004.

[9] WWF. Pakistan's waters at risk, Water and health related issues in Pakistan and key recommendations (2007), pp. 1-33 A special report, WWF - Pakistan, Ferozepur Road, Lahore - 54600, Pakistan.

[10] PAK-EPA. State of Environment Report 2005. Pakistan Environmental Protection Agency (Pak-EPA) Ministry of Environment, Govt. of Pakistan, Islamabad, Pakistan 2005.

[11] S. N. H. Mashadi and Muhammad A. Recharge the depleting aquifer of Lahore Metropolis, In Proceedings of regional groundwater management seminar 2000; 209-220 Islamabad.

[12] J. Samina, M. Jaffar and M. H. Shah. Physico-chemical profiling of ground water of

[13] Hazara strip, Pakistan. J. Chem. Soc. Pakistan. 26, pp. 288292, 2004.

[14] A. Rahman. Groundwater as source of contamination for water supply in rapidly growing megacities of Asia: Case of Karachi, Pakistan. Water Science and Technology. Vol. 34, pp. 285-292, 1996.

[15] K. Khan, Y. Lu, H. Khan, S. Zakir, Ihsanullah, S. Khan, A. A. Khan and L. W. T. Wang. Health risks associated with heavy metals in the drinking water of Swat, northern Pakistan. Journal of Environmental Sciences. Vol. 25, pp. 2003-2013, October 2013.

[16] H. Amjad, I. Hashmi, M. S. Rehman, M. A. Awan, S. Ghaffar and Z. Khan. Cancer and non-cancer risk assessment of trihalomethanes in urban drinking water supplies of Pakistan. Ecotoxicology and Environmental Safety Vol. 91, pp. 25-311, May 2013.

[17] NIH. Survey by the 'Network 'Islamabad: National Institute of Health (NIH), Islamabad-Pakistan. 2004.

[18] UNDP, 2003. Pakistan National Human Development Report, "Water Crisis", Karachi, pp. 7103.
[19] S. Nazeer, M. Z. Hashmi and R. N. Malik. Heavy metals distribution, risk assessment and water quality characterization by water quality index of the River Soan, Pakistan. Ecological Indicators. Vol. 43, pp. 262-270, August 2014.

[20] J. Iqbal, M. H. Shah and G. Akhter. Characterization, source apportionment and health risk assessment of trace metals in freshwater Rawal Lake, Pakistan. Journal of Geochemical Exploration. Vol. 125, pp. 94-101, February 2013.

[21] U. Asghar, F. Parveen, S. K. Alvi, F. A. Khan, I. Siddiqui and T. H. Usmani. Contamination of Arsenic in Public Water supply scheme of Larkana and Mirpur Khas, District of Sindh J. Chem. Soc. Pak. 28, pp. 130-35, 2006.

[22] A. R. Khan, Mumtaz, K. S. Min, G. A. Marwat and M. iaz. Potable water quality characteristics of the urban areas of Peshawar (Pakistan): well water. J. Chem. Soc. Pak. ; 27, pp. 239-245, 2005.

[23] A. R. Khan, A. Haq, A. Waqar, M. Akif, M. Khan and M. Riaz. Quality characteristics of potable water of Mardan city J. Chem. Soc. Pak. 22, pp. 87 -93, 2000.

[24] S. M. Leghari, T. M. Jahangir, M. Y. Khuhawar, A. Laghari and A. D. Rajper, Water quality and biological assessment of ghazi shah and kai springs of district Dadu, Sindh. J. Biol. Sci. Pakistan. 2, pp. 39-42, 2002.

[25] M. Y. Khuhawar and G. M. Mastoi, Studies on some Physico chemical parameters of Mancher lake Sindh. J. Anal. Environ. Chem. 3, pp. 66-71, 1995.

[26] M. N. Bhutta, M. Ramzan and C. A. Hafeez. Ground water quality and availability in Pakistan. Pakistan Council for Research in Water Resources (PCRWR, Islamabad, Pakistan, 2002.

[27] A. Azizullah, M. N. K. Khattak, P. Richter and D. Hader, Water pollution in Pakistan and its impact on public health A review. Environment International. Vol. 37, pp. 479-497, February 2011.

[28] Zahoorullah, T. Akhtar and S. Zai. Quality of drinking water in rural Peshawar. Pak J Med Res, 42, pp. 85-89, 2003.

[29] G. Sarwar, J. Khan, R. Iqbal, A. K. Afridi, A. Khan and R. Sarwar. Bacteriological analysis of drinking water from urban and peri-urban areas of Peshawar. Journal of Postgraduate Medical Institute, Khyber Medical College, Peshawar, 18, pp. 64-69, 2004.

[30] M. Hussain, S. A. Rasool, M. T. Khan and A. Wajid. Enterococci vs coliforms as a possible fecal contamination indicator: baseline data for Karachi. Pak J Pharm Sci, 20, pp. 107-111, 2007.

[31] M. S. Anwar, N. A. Chaudhry and M. Tayyib. Qualitative assessment of bacteriological quality and chlorination status of drinking water in Lahore, J Coll Physicians Surg Pak, 14, pp. $157-160,2004$.

[32] R. T. Nickson, J. M. McArthur, B. Shrestha, T. O. KyawMyint and D. Lowry, Arsenic and other drinking water quality issues, Muzaffargarh District, Pakistan Applied Geochemistry. Vol. 20, pp. 55-68, January 2005. 
[33] K. D. Brahman, T. G. Kazi, H. I. Afridi, S. Naseem, S. S. Arain and N. Ullah. Evaluation of high levels of fluoride, arsenic species and other physicochemical parameters in underground water of two sub districts of Tharparkar, Pakistan: A multivariate study. Water Research. Vol. 47, pp. 1005-1020, March 2013.

[34] Y. Iqbal, S. Alam, S. Sabir, M. Ishaq and N. Ahmad. Investigation of pollutants in the industrial effluents. J. Chem. Soc. Pak. 22, pp. 239-44, 2000.
[35] Z. H. Lodhi, M. Akif and U. Kalsoom, Evaluation of drinking water from different sources in skardu-Northern area with special reference to heavy metals. J. Chem. Soc. Pak. 25, pp. 110-13, 2003.

[36] J. H. Poverty and R. J. Kopka. Water, Air and Soil Pollution. 57, pp. 399, 1995. 